Contents lists available at http://ejournal.uin-suska.ac.id

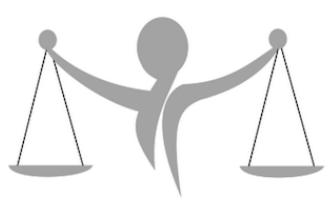

Al-Ittizaan: Jurnal Bimbingan Konseling Islam

ISSN: $2620-3820$

Journal homepage: http://ejournal.uin-suska.ac.id/index.php/alittizaan

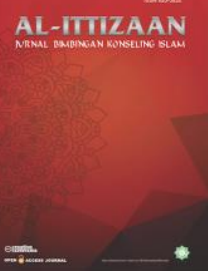

\title{
Pola Asuh Single Parent Dalam mengembangkan Moralitas Anak Di Desa Marga Mulya Kecamatan Rambah Samo Kabupaten Rokan Hulu
}

\author{
Laila Lathifatul Mudrikah ${ }^{1}$ \\ ${ }^{1}$ Universitas Islam Negeri Sultan Syarif Kasim Riau
}

\begin{tabular}{l} 
Article Info \\
Article history: \\
Received Juni $12^{\text {th }}, 2019$ \\
Revised September $10^{\text {th }}, 2019$ \\
Accepted Oktober $26^{\text {th }}, 2019$ \\
\hline
\end{tabular}

\section{Keyword:}

Pola Asuh, Single Parent, Moralitas Anak

\begin{abstract}
Dalam penelitian ini dituliskan berdasarkan judul pada skripsi ini yakni Pola Asuh Single Parent Dalam Mengembangkan Moralitas Anak di Desa Marga Mulya Kecamatan Rambah Samo Kabupaten Rokan Hulu, sebagaimana permasalahannya tentang kesulitan yang dihadapi oleh single parent dalam menjalani peran ganda dikeluarganya sehingga single parent kurang dapat fokus terhadap pengasuhan anaknya sebab harus sibuk bekerja untuk keberlangsungan hidup keluarganya. Sehingga dapat dirumuskan bagaimana Pola Asuh Single Parent dalam mengembangkan moralitas anak di Desa Marga Mulya Kecamatan Rambah Samo Kabupaten Rokan Hulu. Tujuan penelitian ini adalah untuk mengetahui Pola Asuh Single Parent dalam mengembangkan moralitas anak di Desa Marga Mulya Kecamatan Rambah Samo Kabupaten Rokan Hulu. Subjek dalam penelitian ini adalah ibu single parent di Desa Marga Mulya. Dalam kajian ini peneliti menggunakan teori Authoritarian, Permissive dan Authoritative. Teknik pengumpulan data dalam penelitian ini menggunakan teknik observasi, wawancara dan dokumentasi, kemudian jenis penelitian ini yaitu deskriptif kualitatif. Informan dalam penelitian ini adalah 5 orang ibu single parent. Dari hasil penelitian ini diketahui para informan menerapkan pola asuh yang mengarah pada pola asuh permisif dan authoritative dalam mendidik anak mereka dengan cara lebih mencari aman dalam mengasuh, mendidik, dan mengawasi anak sebab kesibukan sebagai ibu single parent yang menyandang dua posisi sebagai tulang punggung keluarga dan ibu untuk anaknya maka ibu single parent tersebut mengasuh anaknya dengan memberikan kebebasan kepada anak, memaklumi segala perilaku anak, kurang menuntut tanggung jawab anak dan perilaku anak namun single parent tetap berusaha memberikan yang terbaik untuk anaknya dengan segala keterbatasan waktu yang dimilikinya.
\end{abstract}

(C) 2019 The Authors. Published by UIN Sultan Syarif Kasim Riau.

This is an open access article under the CC BY license

(https://creativecommons.org/licenses/by/4.0)

\section{Author:}

Laila Lathifatul Mudrikah

Universitas Islam Negeri Sultan Syarif Kasim Riau

Email: laila.latifatul.mudrika@gmail.com

\section{Pendahuluan}

Kehidupan di dunia ini setiap individu pasti memiliki dinamika sosial yang selalu berhubungan dengan keluarga. Keluarga merupakan unsur penting yang selalu ada dalam kehidupan seseorang. Keluarga juga merupakan tempat kembali yang nyaman setelah menghadapi kehidupan di luar yang penuh dengan kebisingan. Terlebih dengan kehadiran anak-anak yang menjadi pengikat hati orang tua. Rasa lelah setelah menyelesaikan 
bertumpuk-tumpuk pekerjaan terbayar saat melihat senyum ceria anak-anak. Sebenarnya, yang dapat dikatakan dengan keluarga lengkap atau utuh yaitu beranggotakan atas ayah, ibu dan anak. Komunikasi dan hubungan sosial yang baik antar anggota keluarga akan menciptakan status dan peran terutama oleh ayah dan ibu untuk menanamkan dan memelihara nilai-nilai dalam keluarga kepada anak. Penyebab "keutuhan" dalam sebuah keluarga sangat mempengaruhi tahap perkembangan diri pada anak. kenyataannya yang ada dalam kehidupan masyarakat adalah keadaan keluarga dengan orang tua tunggal. Single father atau single mother, keduanya umum disebut dengan single parent.

Sebuah keluarga yang tidak utuh atau lengkap apabila hanya beranggotakan ayah dan anak atau ibu dan anak. Keluarga tersebut bisa saja disebabkan perceraian ataupun salah satu orang tua meninggal dunia. Dengan seperti itu keluarga tersebut bisa disebut keluarga single parent dan kemudian akan ada perubahan peran dan tanggung jawab tugas yang harus diterapkan untuk mengasuh anak. Hak atau kewajiban mendidik anak merupakan beban sosial yang lebih berat yang dimiliki oleh kaum ibu dengan status single parent. Single parent harus menjalankan peran ganda untuk keberlangsungan hidup keluarganya. Status single parent pasca perceraian menjadikan akibat perubahan peran pada ibu. Ia tidak hanya menjadi ibu tetapi juga menjadi kepala keluarga yang harus mencari nafkah. Ibu single parent dituntut untuk menjalankan beberapa peran dan mengambil tanggung jawab penuh baik dalam bidang ekonomi, pendidikan, atau cara mengambil keputusan yang tepat untuk mempertahankan kelangsungan hidup keluarganya. Dari hal tersebut perubahan peran pada keluarga yang besar itu menjadikan seorang ibu single parent senantiasa berjuang menjadi tulang punggung bagi keluarga dan terlebih bagi penggunaan pola asuh yang diterapkan pada anak yang dapat mempengaruhi perkembangan moralitas si anak(Hadi \& Zubaidah, 2015).

Pada suatu kondisi perceraian dengan pasangan dianggap sebagai jalan terbaik daripada hidup bersama namun justru saling menyakiti anggota keluarga. Tugas parenting dirasa sangat berat dilakukan oleh ibu single parent bersamaan dengan tugas mencari nafkah dan yang wajib sekali ialah memberikan pendidikan moral sehingga anak dapat berkembang dengan baik. Korban utama dari perceraian ataupun kematian suami adalah anak-anaknya. Kondisi yang serba sulit ini menjadikan alasan para ibu single parent untuk lebih berjuang lagi demi kewajibannya mendidik anak. Meckupi kebutuhannya materinya saja tidak cukup untuk menjadikan anak-anak tangguh menghadapi tantangan hidup.

Uang dan materi hanyalah sebuah alat. Saat orang tua tidak mendidik anak bijaksana membelanjakan uang dijalan kebaikan, maka uang inilah yang akan menjerumuskan anak ke dala keburukan yang sangat mengerikan. Tentu ibu single parent tidak ingin sesuatu yang diperjuangkannya secara mati-matian untuk anaknya justru menjadi bumerang bagi mereka sebab tidak pandai membelanjakannya dalam hal kebaikan. Kesalahan tetap terletak dipundak orang tua yang enggan mendidik anak-anaknya dengan baik. Jangan sampai ibu single parent menjadi slah satu orang tua yang tidak bertanggung jawab. Oleh sebab itu ibu single parent harus bersiap menghadapi kenyataan kehidupan dan harussegera bangkit dari perceraian ataupun kematian suaminya.

Perjuangan ibu single parent saat ini bukanlah hal yang sangat mudah dan perjuangan ini bukanlah seperti mengusir penjajah, namun mengusir hal-hal negatif yang dapat merusak masa depan anaknya yang pernah tumbuh dan berkembang dirahim ibu single parent (Nurhayati, 2017). Menurut Purwa Atmaja Prawira dalam suatu keluarga, orang tua yang mengetahui kepribadian masing-masing anggota keluarganya, seperti suami atau isteri dan anak-anaknya maka akan dapat menghasilkan suatu kebahagiaan dalam keluarga termasuk sikap keterbukaan padang masing-masing. Misalnya, orang tua yang mengetahui kepribadian anakanaknya, seperti sifat, bakat, dan kegemaran atau hobi akan dapat mengarahkan atau memberikan bimbingan yang sesuai dengan kepribadian dirinya. Demikian, di dalam keluarga terhindar dari hal-hal yang tidak menyenangkan sehingga akan ditemukan kunci kebahagiaan keluarga (Prawira, 2014). Dalam setiap keluarga para orang tua memiliki keinginan dan harapan kepada anaknya agar memiliki kepribadian yang baik dan salah satunya ialah moral yang baik. Orang tua merupakan panutan dan sebagai sumber utama untuk anak dalam pembentukan pribadi anak dalam keluarga.

Kewajiban para orang tua dalam usaha mengembangkan pribadi dan moral anak yaitu dengan cara mendidik, membimbing dan memberikan pengasuhan pada anak. Kemudian memberi perlindungan, memberikan rasa cinta kepada anak-anak agar kedepannya anak juga memiliki rasa kasih sayang kepada sesama (Mutiah, 2012). Ibu single parent adalah sebuah keluarga dimana posisi orang tua hanya ada seorang ibu yang sedang berjuang untuk mengasuh anaknya sendirian pasca perceraian ataupun seuami meninggal dunia. Tujuan Penelitian ini adalah untuk mengetahui pola asuh yang diterapkan oleh ibu single parent dan kontribusinya terhadap perkembangan moral anak. Syamsu Yusuf dalam bukunya mengutip pendekatan tipologi yang dipelopori oleh "Diana Baumrind" mengajukan tiga pola pengasuhan sebagai kombinasi dari dua faktor tersebut, yaitu authoritative atau democrative, authoritarian dan permissive (L.N, n.d.) 
Berdasarkan teori Baumrind yang dikutip oleh Syamsu Yusuf dalam bukunya menjelaskan bahwa pola asuh orang tua terhadap anak terdapat tiga macam bentuk, diantaranya:

1. Pola Asuh Menang (Authoritarian)

Dalam pola asuh ini, orang tua selalu berusaha membentuk, mengontrol, mengevaluasi perilaku dan tindakan anak agar sesuai dengan aturan standar. Aturan tersebut biasanya bersifat mutlak dan diberlakukan dengan otoritas yang tinggi. Anak-anak kurang mendapat penjelasan yang masuk akal atas segala aturan, kurang dihargai pendapatnya, dan orang tua kurang peka terhadap kebutuhan dan persepsi anak, orang tua suka melakukan hukuman secara fisik kepada anak dan bersikap keras kepada anak, cenderung orang tua emosional dan bersikap menolak. Perilaku yang ditimbulkan anak dengan pola asuh authoritarian tersebut yaitu: mudah tersinggung, penakut, pemurung, tidak bahagia, mudah terpengaruh, mudah stres, tidak mempunyai arah masa depan yang jelas, tidak bersahabat (L.N, n.d.)

2. Pola Asuh Mengalah (Permissive)

Pola asuh yang permisif biasanya dilakukan oleh orang tua yang terlalu baik, memberi kebebasan pada anak-anak dengan menerima dan memaklumi segala perilaku, namun kurang menuntut sikap tanggung jawab dan keteraturan perilaku anak. Orang tua yang demikian akan menjadi pemenuh atas segala kebutuhan dan kemauan anak, membiarkan anak untuk mengatur dirinya sendiri. Perilaku yang ditimbulkan pada anak dengan pola asuh Permissive tersebut yaitu: bersikap implusif dan agresi, sering memberontak, kurang memiliki rasa percaya diri dan sulit mengendalikan diri, suka mendominasi, prestasinya rendah (L.N, n.d.).

3. Pola Asuh Tidak Menang Tidak Kalah (Authoritative)

Pola asuh authoritative atau democrative adalah pola asuh orang tua yang mengarahkan perilaku anak secara rasional, dengan memberikan penjelasan terhadap maksud dari aturan-aturan yang diberlakukan serta memberikan penjelasan tentang dampak perbuatan yang baik dan yang buruk. Orang tua mendorong anak untuk mematuhi aturan dengan kesadaran sendiri dan mendorong anak untuk menyatakan pendapat. Selain itu orang tua juga menghargai anak dan kualitas kepribadian yang dimiliki anak.

Perilaku yang ditimbulkan terhadap anak dengan pola asuh authoritative tersebut yaitu: bersikap eazy going, memiliki rasa percaya diri, mampu mengendalikan diri, bersikap sopan, rasa ingin tahunya tinggi, mempunyai arah hidup yang jelas, berorientasi terhadap prestasi (L.N, n.d.).

Bagaimanapun juga anak-anak akan menjadi investasi kebahagiaan di dunia dan di akhirat. Pada mereka orang tua menitipkan cita-cita mulia yang tinggi dan belum sempat mewujudkannya. Di tangan mereka catatan amal kebaikan akan terus mengalir meskipun orang tua sudah meninggal dunia. Dengan begitulah ibu single parent harus berusaha keras dalam menafkahi dan mendidik anaknya sehingga anak tersebut memiliki moral yang baik walaupun anak tersebut berada dalam keluarga yang tidak utuh.

Moralitas orang tua disebuah keluarga itu sangatlah penting sebab menjadikan suatu contoh untuk pendidikan moral yang diajarkan orang tua pada anak dengan begitu anak akan secara alami meniru setiap apapun yang dilakukan oleh orang tuanya. Pendidikan moral tersebut dikatakan pendidikan non formal yang dilakukan orang tua setiap saat berada dirumah tetapi akan sangat menimbulkan efek positif pada diri anak. Maka tidak mudah ketika orang tua harus memberikan pendidikan pada anak dengan sendirian karena kondisi ibu single parent harus menjalani dua peran dalam keluarga untuk sang anak.

Pada masa-masa memasuki tahap-tahap perkembangan psikologis anak, seorang anak biasanya akan berubah menjadi lebih mudah terpengaruh dan pemberontak, sebab disaat seperti inilah anak masih dalam suasana mencari jati dirinya, anak juga akan sering terjerumus dalam pergaulan yang salah pada lingkungan luar rumahnya. Sudah hal yang lumrah bahwa setiap saat anak melakukan kesalahan, maka masyarakat pertama kali akan menimpakan kesalahan tersebut pada orang tuanya, bagaimana cara mendidik anaknya. Terlihat dari gambaran diatas sangat jelas bahwa tugas seorang ibu single parent cukup berat, dan lebih berat lagi apabila anak-anaknya telah menginjak dewasa. Dalam kehidupan rumah tangga ibu mempunyai peranan yang sangat penting dalam mendidik dan mengembangkan moral anak menjadi lebih baik.

Meskipun ibu single parent memiliki kesibukan dalam mencari nafkah akan tetapi ibu single parent tetap berusaha membagi waktunya dan berusaha keras dalam membimbing, memantau dan mengarahkan tumbuh kembang anak dan memberikan anak-anaknya pendidikan formal, informal, dan non formal. Ibu single parent dengan keterbatasan waktunya masih berusaha menanamkan 
pengetahuan moral, perasaaan moral dan mewujudkan tindakan moral bagi anak-anaknya walaupun tidak bisa maksimal.

Hal Yang Perlu Diperhatikan Ibu Single Parent Dalam Mengembangkan Moralitas Anak Diantaranya Sebagai Berikut:

a. Figur Ibu Teladan Dalam Rumah Tangga

Sebagai teladan utama, seorang ibu hendaklah bersifat jujur dalam segala tindaktanduknya, baik terhadap anak-anaknya. Suaminya atau pun terhadap anggota keluarga yang lain, begitu pula terhadap tetangga dan anggota masyarakat lainnya. Bila sang ibu ingin mendidik untuk membiasakan anaknya bersifat "amanah" maka terlebih dahulu ia sendiri harus memiliki sifat yang demikian terhadap siapapun dan apapun yang ada dikeluarganya. Bila ia ingin mendidik dan membiasakan anaknya untuk memiliki sifat kasih sayang dan pemurah, maka terlebih dahulu ia sendiri harus memberi contoh dalam hal mengerjakan tugas-tugas rumah tangga dengan penuh kasih-sayang.

Sehingga anak dapat merasakan secara langsung penerapan dari perasaan itu. Misalnya, cara menyambut tamu dengan penuh hormat dan ramah, menyantuni fakir miskin dan menyayangi binatang. Dengan melakukan hal-hal diatas di hadapan sang anak, berarti ibu telah menanamkan nilai-nilai dan prinsip-prinsip moral yang mulia dalam diri anaknya, berupa rasa cinta, tolong menolong, sikap amanah dan sifat jujur (Husain, 1991).

b. Upaya orang tua memberi pendidikan kepada anak untuk membentuk moral anak

Pertama, Memberi Tanggapan Positif, termasuk cara untuk mengajarkan anak yang berhubungan dengan sikap mereka. Ketika orang tua berkata kepada anak kalau orang tuanya sangat menyukai dan menghargai anak sebab anak telah mengikuti nasehat yang diberikan maka anak akan terus mengulangi tindakan tersebut.

Kedua, Tidak Ada Respon, merupakan langkah orang tua untuk mengajarkan kepada anak dengan orang tua bersikap mengabaikan sikap anak. Maka setelah sikap-sikap anak tidak direspon oleh orang tua maka akhirnya nanti anak cenderung tidak mengulangi lagi sikap tersebut. Maksud dari diabaikan sikap anak tersebut ialah sikap yang menurut orang tua sangat mengganggu perkembangan pribadi anak.

Ketiga, Melakukan Pemberian Contoh dalam segala tindakan, merupakan metode pokok yang diberikan oleh orang tua untuk mengajarkan kepada anak. Pengaruhnya terhadap anak ialah anak lebih cepat memahami apa yang orang tua lakukan melalui mencontohkan tadi dari pada melalui apa yang dikatakan oleh orang tuanya hanya dengan sebuah kata-kata.

Keempat, Memberi Hukuman, merupakan cara terakhir orang tua memberikan pelajaran kepada anak-anak. Walaupun hukuman dapat dikatakan cara yang efektif dibandingkan dengan ketiga cara diatas namun lebih banyak efek buruknya terhadap perkembangan psikis anak, seperti menjadikan anak bersikap negatif, sangat emosional dan tidak bisa mengendalikan dirinya (C.Drew, 2006).

Orang tua memang sangat berperan penting terhadap pengasuhan anaknya untuk menjadikan anaknya menjadi pribadi yang baik. Firman Allah SWT dalam surat Luqman ayat 17:

Artinya: "Hai anakku, dirikanlah shalat dan perintahlah (manusia) mengerjakan perbuatan yang baik dan cegahlah (mereka) dari perbuatan yang buruk dan bersabarlah terhadap apa yang menimpa kamu. Sesungguhnya yang demikian itu termasuk hal-hal yang diperintahkan oleh Allah" (Depertemen Agama RI, 2014). Dari beberapa pendapat para ahli diatas pola asuh berarti bentuk tanggung jawab orang tua dalam membimbing, merawat dan mendidik anaknya hingga dewasa.

Ketidaksempurnaan keluarga menjadi legalitas baginya untuk melakukan kesalahan-kesalahan yang semakin besar dalam membangun rumah tangga di masa depan. Namun saat parenting berhasil maka orang tua akan merasakan manisnya memberikan bekal bagi anak untuk menghadapi tantangan kehidupan di masa depan yang tentunya lebih berat dibandingkan tantangan hidup saat ini. Setiap orang pasti akan diuji di titik terlemahnya. Bisa jadi ketidaksempurnaan keluarga atau seperti yang dialami oleh ibu single parent inilah titik pacu kekuatan berkali-kali lipat dalam diri ibu single parent tersebut(Hadi, Yusuf, \& Syahniar, 2013).

Dapat dikatakan bahwa anak merupakan pondasi harapan bagi orang tua dalam kehidupan keluarga di ruang lingkup kecil dan merupakan asset bangsa dalam ruang lingkup yang lebih luas dimasa yang akan datang. Keluarga ibu single parent berusaha memberikan pengasuhan kepada anaknya dengan baik karena mereka sadar bahwa keluarga mereka memiliki kekurangan yang tidak dimiliki seperti halnya keluarga utuh. 
Gejala-gejala pada penelitian pola asuh single parent dalam mengembangkan moralitas anak di Desa Marga Mulya Kecamatan Rambah Samo Kabupaten Rokan Hulu adalah sebagai berikut:

1) Ibu single parent belum mampu memberikan perhatian penuh terhadap anak karena kesibukan menjalani peran ganda di keluarga.

2) Kesulitan atau kendala ibu single parent dalam mengembangkan moral anak. Misalnya: ketika ibu single parent sedang mencari nafkah untuk anaknya menyebabkan ibu single parent kesulitan untuk mengatur waktu antara fokus untuk mengasuh dan mendidik anaknya dengan bekerja untuk mencari nafkah demi menghidupi keluarganya.

Berdasarkan dari paparan di atas, peneliti tertarik untuk melakukan penggalian yang lebih dalam. Hasil observasi yang peneliti lakukan pada Desa Marga Mulya tersebut memang terdapat beberapa ibu single parent yang sedang berusaha mengasuh anak-anaknya seorang diri. Disini peneliti memusatkan perhatian pada pola asuh ibu single parent terhadap anak dalam mengembangkan moral. Maka dari itu peneliti mengambil judul "POLA ASUH SINGLE PARENT DALAM MENGEMBANGKAN MORALITAS ANAK DI DESA MARGA MULYA KECAMATAN RAMBAH SAMO KABUPATEN ROKAN HULU".

\section{Metode Penelitian}

Dalam mendapatkan data, peneliti menggunkan teknik pengumpulan data yaitu: observasi, wawancara dan dokumentasi. Adapun validitas data yang digunakan dalam penelitian ini ialah dengan menggunakan teknik tringulasi sumber data. Tringulasi dengan sumber adalah menggali informasi tertentu melalui berbagai metode dan sumber perolehan data (Ruslan, 2008). Kemudian informan dalam penelitian ini ada informan diantaranya yaitu: informan kunci, adalah mereka yang mengetahui dan memiliki berbagai informasi pokok yang dibutuhkan dalam penelitian sedangkan informan pendukung, adalah mereka yang terlibat secara langsung dalam interaksi sosial yang diteliti yaitu seperti anggota keluarga (anak).

\section{Hasil Penelitian}

Dapat diketahui bahwa Ibu Suparti Ningsih berusia 41 tahun. Seorang ibu single parent disebabkan oleh perceraian dan sudah menjalani statusnya sebagai single parent selama 8 tahun. Profesinya sebagai seorang guru SD. Anaknya bernama Felix Raihan merupakan anak yang ke 2 berumur 12 tahun. Menurut ibu Suparti Ningsih yang merupakan tanggung jawab orang tua terhadap anaknya adalah mendidik dan memberikan pendidikan kepada anak agar anak memiliki pribadi yang baik dan moral yang baik. Selain dari pada itu tanggung jawab orang tua ialah berusaha untuk dapat memenuhi segala kebutuhan anak baik kebutuhan primer ataupun sekunder bahkan tersier. Menurut ibu Suparti Ningsih lebih baik mencari aman dengan cukup menasehati dan membimbing jika anak melakukan kesalahan dan tidak memberi hukuman kepada anak sebab anak akan lebih berani menentang dan membantah orang tua jika diperlakukan seperti itu. Ibu Suparti Ningsih tidak menutut anaknya untuk bertanggung jawab dengan apa yang sudah dilakukannya.

Ibu Suparti Ningsih memberikan kebebasan jika anak ingin bergaul dengan teman-temannya dan anak bisa menjaga dirinya disetiap dia bergaul dengan temannya serta dapat memenuhi aturan yang sudah dibuat bersama. Ibu Suparti Ningsih bersikap terbuka kepada anaknya sehingga anak bersikap terbuka juga kepadanya. Maka tidak ada sesuatu yang harus dirahasiakan dari orang tua. ibu Suparti Ningsih berusaha untuk selalu memberikan apa yang diinginkan oleh anaknya jika yang diinginkan itu penting dan tidak mengganggu sekolahnya. Sebab jika tidak dikabulkan permintaan anak maka anaknya akan mengamuk dan itu dapat mengganggu konsentrasi Ibu Suparti Ningsih dalam bekerja. Jadi menurut ibu Suparti Ningsih lebih baik mencari aman dengan menuruti apa keinginan anaknya. Ibu Suparti Ningsih berusaha memantau dan menyuruh anaknya untuk melakukan ibadah sholat 5 waktu walaupun ibu Suparti Ningsih dalam keadaan sibuk bekerja namun baginya ibadah itu hal yang terpenting untuk diajarkan kepada anaknya karena merupakan hal yang membentuk moral si anak.

Uraian diatas dapat diketahui bahwa kriteria pengasuhan yang dilakukan oleh ibu Suparti Ningsih yaitu:

1. Berusaha mengawasi anak dalam melakukan kegiatan

2. Tidak membatasi anak bergaul dengan temannya

3. Memberikan kebebasan anak untuk bertindak

4. Menasehati dan membimbing anak jika melakukan kesalahan 


\section{Tidak menuntut tanggung jawab anak dalam berperilaku}

Dapat diketahui bahwa ibu Estri Sutriani berusia 36 tahun. Seorang ibu single parent disebabkan oleh perceraian dan sudah menjalani masa single parent selama 10 tahun. Profesinya sebagai ibu rumah tangga dan memiliki warung sembako sederhana, anaknya bernama Dina merupakan anak pertama berumur 12 tahun. Menurut ibu Estri Sutriani menjadi single parent itu tanggung jawabnya besar karena harus mendidik anak seorang diri dan juga memenuhi kebutuhan si anak. Belum lagi ketika anak membuat masalah cuma ibu lah yang bertanggung jawab tanpa ada suami. Ibu Estri Sutriani memberikan pengasuhan untuk anaknya tidaklah dengan sikap yang keras namun memberikan kebebasan untuk anaknya dalam bertindak namun kurang sekali memiliki waktu untuk bisa memantaunya.

Disaat anaknya melakukan kesalahan ibu Estri Sutriani pun tidak menghukumnya tapi menasehati dan membimbingnya agar tidak mengulangi kesalahannya, dan ketika anak ingin pergi bermain dengan temannya ibu Estri Sutriani pun mengizinkannya sebab kalau nanti dilarang-larang malah justru akan menambah beban saya karena ditakutkan anaknya akan memberontak maka dari itu ibu Estri Sutriani memilih untuk memberinya kebebasan. Menurut ibu Estri Sutriani mendidik anak agar memiliki moral yang baik itu tidaklah mudah banyak proses dan tantangan yang harus dilalui agar tetap sabar dan istiqomah dalam tujuan mengembangkan moral anaknya dengan baik.

Ketika anaknya memiliki masalah selalu menceritakan kepadanya dan ibu Estri Sutriani pun berusaha memberikan nasehat terbaik untuk anaknya. Ibu Estri Sutriani memperhatikan anaknya dalam melakukan ibadah sholat 5 waktu dan berusaha mengingatkan anaknya untuk melakukan sholat. Sebab menurut ibu Estri Sutriani untuk membentuk moral yang baik pada anaknya adalah dengan menanamkan nilai religius seperti beribadah sholat dan dibarengi dengan ibadah-ibadah mulia lainnya.

Uraian diatas dapat diketahui bahwa kriteria pengasuhan yang dilakukan oleh ibu Estri Sutriani yaitu:

1. Tidak mengekang anaknya dalam melakukan kegiatan

2. Berusaha menasehati dan membimbing anak ketika melakukan kesalahan

3. Memberikan kebebasan kepada anak dan tidak memberikan peraturan yang bersifat memaksa

4. Tidak menuntut sikap tanggung jawab anak

Dapat diketahui bahwa ibu Lili Ani berusia 39 tahun. Seorang ibu single parent disebabkan oleh kematian suaminya dan sudah mennyandang status sebagai single parent selama 3 tahun. Profesinya sebagai ibu rumah tangga dan mengurus kebun peninggalan suaminya dan memiliki penangkaran burung wallet, anaknya bernama Rafif merupakan anak ke 3 berumur 7 tahun. Menurut ibu Lili Ani justru membiarkan anaknya untuk melakukan apa saja selama perilaku anaknya tidak menyimpang. Ibu Lili Ani menganggap anaknya sudah tahu mana yang boleh dilakukan dan mana yang tidak boleh dilakukan, sehingga ibu Lili Ani cenderung membiarkan anaknya ketika bermain diluar rumah. Jika anak melakukan kesalahan ibu Lili Ani tidak pernah menghukumnya namun hanya menasehatinya agar tidak mengulangi kesalahannya. Ibu Lili Ani memberikan pengasuhan secara baik dan tidak mengajarkan anaknya untuk berbuat buruk dengan selalu mencontohkan kepada anaknya perbuatan yang bermanfaat dan tidak melukai orang lain dan juga tidak terlalu mengekang anaknya untuk selalu mengikuti kemauan ibu Lili Ani karena menurut ibu Lili Ani menjadi single parent tidaklah mudah dengan 2 posisi yang harus dijalani.

Ketika anaknya meminta sesuatu jika ada uang maka dibelikannya namun juga berdasarkan penting tidaknya keinginan anaknya. Walaupun dalam kesibukan bekerja ibu Lili Ani tetap berusaha menyuruh anaknya melakukan sholat 5 waktu dan mengontrolnya sebab ibu Lili Ani memberikan penjelasan kepada anaknya kalau sholat 5 waktu itu merupakan kewajiban umat muslim dan menjadikan kita sebagai manusia yang sempurna dimata allah ketika ibadah dan moral kita baik.

Uraian diatas dapat diketahui bahwa kriteria pengasuhan yang dilakukan oleh ibu Lili Ani yaitu:

1. Mengikuti kemauan anaknya

2. Memberikan kebebasan untuk anaknya dalam melakukan sesuatu

3. Menasehati dan membimbing anak ketika anak bersalah

4. Tidak menghukum dengan kekerasan

Dapat diketahui bahwa Ibu Kasiah berusia 47 tahun. Seorang ibu single parent disebabkan oleh kematian suaminya dan sudah menyandang status sebagai single parent selama 11 tahun. Profesinya sebagai IRT dan mengolah kebun peninggalan suaminya, anaknya bernama Ilham Sayekti anak yang ke 4 berumur 13 tahun. Menurut ibu Kasiah menjadi orang tua sebagai single parent itu harus dapat menjalani dua peran sekaligus yaitu ketika kita bekerja menjadi sosok ayah dan ketika kita mengasuh anak maka menjadi sosok ibu. Menurut Ibu 
Kasiah semua orang tua menginginkan anaknya mejadi anak yang baik dan juga memiliki perilaku yang baik pula. Ketika anak berbuat kesalahan itu merupakan hal yang biasa namanya juga masih anak-anak, jangankan anak-anak yang sudah dewasa saja bisa melakukan kesalahan. Salah satu tanggung jawab orang tua dalam hal ini adalah memberikan nasehat, mengajarkan kebaikan kepada anak, dan jauhilah sikap emosional yang negatif terhadap anak yang dapat merusak psikisnya. Menurut Ibu Kasiah ketika anaknya menginginkan sesuatu seperti ingin pergi bermain dengan temannya maka ibu tersebut memberinya izin. Dan Ibu Kasiah juga sudah mensugesti dirinya bahwa anaknya dapat menjaga dirinya dengan baik ketika bermain diluar sana. Namun Ibu Kasih tetap berusaha untuk mengawasi anaknya walaupun dengan keterbatasan waktu yang dimilikinya.

Ketika anaknya meminta sesuatu maka Ibu Kasiah memikirkan dahulu penting atau tidaknya barang yang diminta oleh anaknya untuk dibelikan. Sebab menurut Ibu Kasiah ada saatnya sesekali permintaan anak tidak dituruti supaya anak belajar agar dapat memahami keadaan. Naun ketika yang dimintanya itu sangat penting Ibu Kasiah pun langsung mengabulkan permintaan anaknya. Anak ibu Kasiah ketika mempunyai masalah baik dengan teman atau siapapun terkadang anaknya mau bercerita kepadanya dan minta solusi untuk masalahnya. Akan tetapi karena kesibukan sebagai ibu single parent yang harus melakukan apapun demi keluarga seorang diri untuk memnuhi segala kebutuhan hidup keluarga sehingga Ibu Kasiah kurang memiliki waktu untuk bisa berkumpul lebih lama dengan anaknya. Ibu Kasiah juga berusaha memperhatikan anaknya dalam menjalankan ibadah sholat.

Uraian diatas dapat diketahui bahwa kriteria pengasuhan yang dilakukan oleh ibu Kasiah yaitu:

1. Selalu memaklumi sifat anaknya

2. Memberikan apa yang diminta oleh anaknya

3. Mencari aman dengan cara membebaskan anaknya untuk melakukan kegiatan apapun

Dapat diketahui bahwa Ibu Tarmiah berusia 40 tahun. Seorang ibu single parent disebabkan oleh perceraian dan sudah menyandang status sebagai single parent selama 6 tahun. Profesinya sebagai petani dan seorang penjahit, anaknya bernama Nabila anak yang ke 3 berumur 10 tahun. Menurut ibu Tarmiah peran sebagai single parent dan juga orang tua sepenuhnya adalah merawat, menafkahi dan yang terlebih penting adalah memberikan pendidikan yang baik untuk anak supaya anak menjadi orang baik nantinya. Pendidikan agama sanngatlah penting untuk diterapkan kepada anak diusia dininya. Sebab dengan bekal keagamaan tersebut maka perkembangan pribadi dan moral anak akan berkemabang dengan baik. Menurut Ibu Tarmiah sesorang ibu itu merupakan ladang madrasah bagi anak-anaknya. Maka Ibu Tarmiah lebih menekankan anaknya untuk banyak memperoleh bimbingan dan pendidikan yang bersifat keagamaan.

Semua orang tua yang tunggal ataupun utuh pasti menginginkan anaknya memiliki kepribadian yang baik sebab orang tua ingin melihat anaknya sukses dan memiliki perilaku yang baik pula. Ketika anak Ibu Tarmiah berbuat salah ibu tidak pernah menghukum anaknya apalagi sampai bersikap keras kepada anak, Ibu Tarmiah tidak pernah melakukannya. Yang dilakukan Ibu Tarmiah ketika anak melakukan kesalahan yaitu dengan cara membimbingnya. Menurutnya kesalahan yang dibuat anak itu hal yang wajar sebab anak-anak belum begitu mengerti tentang hal yang baik dan yang buruk. Menurut Ibu Tarmiah, orang tua yang baik itu tidak menghukum anak ketika anaknya melakukan kesalahan namun memberikan penjelasan atau bimbingan kearah yang positif kepada anak agar anak mengerti dan memahai letak kesalahannya.

Ibu Tarmiah tidak membatasi bahkan melarang anaknya untuk bergaul dengan temannya yang manapun, yang terpenting itu anaknya dapat menjaga dirinya dan mengontrol perilakunya ketika bermain dengan teman-temannya. Ketika anak Ibu Tarmiah menginginkan sesuatu jika ada uang pasti diberikan tetapi anak suka marah-marah ketika anak sedang ingin sesuatu dan uangnya belum ada, apalagi saat Ibu Tarmiah menanyakan kepada anaknya tentang barang yang diinginkan penting atau tidak malah ini semakin mempeburuk keadaan menjadikan anaknya semakin mengmuk dan ini yang mengganggu kefokusan Ibu Tarmiah dalam bekerja. Namun Ibu Tarmiah berusaha untuk menasehati anaknya agar dapat mengerti keadaan orang tuanya dan Ibu Tarmiah sangat kesal dengan dirinya sendiri sebab kurang dapat mengawasi tindakan anaknya secara maksimal. Ibu Tarmiah pun mengingatkan anaknya dalam melaksanakan ibadah sholat 5 waktu karna baginya itu adalah kewajiban bagi umat muslim.

Uraian diatas dapat diketahui bahwa kriteria pengasuhan yang dilakukan oleh ibu Tarmiah yaitu:

1. Tidak membatasi anaknya untuk berteman dengan siapapun

2. Memenuhi keinginan anak

3. Memberikan kebebasan untuk anak dan menasehati jika anak bersalah

4. Mengikuti kemauan anak tanpa memberikan peraturan yang bersifat memaksa. 
Pada setiap keluarga, orang tua memberikan pola pengasuhan yang berbeda-beda terhadap anaknya. Apalagi dengan ibu single parent yang mana harus menyandang 2 peran dalam keluarga, yaitu harus tetap mejadi sosok ibu dan juga harus menjadi tulang punggung untuk mencari nafkah pengganti dari sosok ayah dari anakanaknya. Mengasuh dan mendidik anaknya untuk menjadi anak yang memiliki perilaku baik adalah keinginan pada semua orang tua. Kesulitan yang sangat berat dihadapi oleh ibu single parent ini harus dijalankan demi keberlangsungan hidup keluarganya dan terlebih lagi untuk pendidikan masa depan anaknya.

Berbagai peran harus ibu single parent jalani dalam satu waktu. Selain mengatur urusan keluarga, juga mencarikan sekolah yang terbaik untuk pendidikan anaknya, berinteraksi dengan masyarakat, hingga menghadapi kenakalan-kenakalan anaknya dan juga problematika lainnya pada keluarga. Saking banyaknya pekerjaan dan urusan yang harus diselesaikan oleh ibu single parent, seolah-olah kesibukannya tersebut tidak akan pernah ada akhirnya walaupun tubuh kelelahan. Namun ibu single parent tetap semangat dan tidak ada rasa mengeluh karena anaknya merupakan penyebangat dalam kehidupannya untuk selalu bangkit dan tidak terpuruk.

Hasil penelitian ini berdasarkan observasi dan wawancara yang dilakukan oleh peneliti tentang pola asuh single parent dalam mengembangkan moralitas anak di Desa Marga Mulya Kecamatan Rambah Samo Kabupaten Rokan Hulu, berdasarkan ke 5 informan tersebut menerapkan pola asuh permissive dan authoritative untuk mengasuh anaknya. Setelah dianalisis oleh peneliti bahwa hasil penelitian ini sejalan dengan teori yang digunakan oleh peneliti yaitu teori Permissifdan Authoritative dari Diana Baumrind yang mana teori Permissifdan Authoritative biasanya dilakukan oleh orang tua yang terlalu baik dan mengalah, lebih banyak memberikan kebebasan pada anak dengan memaklumi semua sikap dan tindakan anak, akan tetapi kurang memperhatikan sikap tanggung jawab dan keserasian perilaku anak (L.N, n.d.). Sehingga anak dari single parent tersebut bersikap pemanja, suka menjadi pemarah ketika keinginannya tidak dipenuhi oleh orang tuanya, sangat menuntut, emosional dan tidak dapat mengendalikan dirinya.

Hal yang menjadikan alasan para informan melakukan pola asuh tersebut disebabkan oleh kesibukan mereka yang harus menjalani dua peran sekaligus yaitu sebagai sosok ayah dan ibu untuk anaknya, yang harus berkerja mencari uang untuk memenuhi kebutuhan keluarga dan keberlangsungan keluarganya serta memberikan pendidikan dan mengasuh anaknya sendirian, dengan kesibukan itulah maka menimbulkan mereka tidak memiliki banyak waktu luang untuk membimbing dan mengawasi kegiatan anak. Anaknyapun tumbuh berkembang dengan kurangnya perhatian dari orang tua.

Anak yang dibesarkan oleh orang tua dengan pola asuh permissive biasanya menjadi anak yang manja, sangat menuntut, kurang percaya diri dan kurang bisa mengendalikan diri mereka tidak menetapkan tujuan atau menikmati kegiatan yang mengandung tanggung jawab (L.N, n.d.). Mereka bisa jadi senang dan bersikap baik selama segala sesuatu berjalan sesuai dengan keinginan mereka, tetapi mudah frustasi jika keinginan mereka tidak terpenuhi.

Posisi orang tua memang sangat rumit jika anak menginginkan sesuatu dan meminta izin untuk bermain dengan teman-temannya semua diberikan dengan alasan orang tua sayang terhadap anaknya. Dan juga orang tua single parent beralasan mengizinkan semua yang anak inginkan karena single parent juga tidak mau kesulitan dengan kesibukannya yang tidak hanya mengasuh anak namun juga harus fokus bekerja. Mengabulkan semua permintaan anak supaya ibu single parent tetap bisa fokus bekerja, maka ibu lebih mencari aman dengan cara tersebut. Dari pada anaknya mengamuk ataupun marah-marah terhadap ibunya sebab tidak dipenuhi keinginannya.

Hal tersebut juga dilakukan oleh ke 5 informan pada penelitian ini agar tidak ada kericuhan yang terjadi antara ibu dan anak. Sebab kalau kericuhan terjadi maka ibu single parent sangat kesulitan untuk meredam kemarahan anaknya seorang diri. Para ibu single parent juga kurang menekankan rasa tanggung jawab untuk dimiliki oleh anaknya, ketika anak berbuat salah justru itu semua dianggap sesuatu yang wajar ketika anak-anak yang melakukan.

Perilaku yang ditimbulkan dari pola pengasuhan yang dilakukan oleh ibu single parent di Desa Marga Mulya terhadap perkembangan moral anaknya yaitu :

1. Anak menjadi pemarah jika kemauannya tidak dipenuhi

2. Anak tidak memiliki rasa tanggung jawab setelah melakukan kesalahan

3. Anak gemar bermain dan bergaul dengan siapapun tanpa ingat waktu

4. Anak suka memberontak 
5. Anak masih mau berusaha menerima nasehat dari orang tua

Berdasarkan hasil penelitian ini Para ibu single parent menginginkan pengasuhan yang baik untuk anaknya. Dengan keterbatasan waktu yang dimilikinya maka ibu single parent kurang puas dengan pola asuh yang diterapkan untuk anaknya. Bukan berarti ibu single parent tersebut menerapkan pola asuh yang demikian merupakan ibu yang buruk, pendendam dan tidak bisa mengendalikan amarah namun hal itu dilakukan sebab ibu single parent ingin tetap bangkit dan tidak mau terpuruk dalam keadaan. Dan juga tetap menginginkan pengasuhan untuk anaknya dilakukan seorang diri dengan segala kemampuannya.

\section{Kesimpulan}

Berdasarkan hasil penelitian ini telah diuraikan dengan pengambilan data menggunakan observasi dan wawancara yang dilakukan oleh peneliti dengan ibu single parent di Desa Marga Mulya, maka dapat diambil kesimpulannya bahwa:

Para 5 Informan (ibu single parent) dalam mengasuh anaknya menggunakan pola asuh permissive dan authoritative dalam memberikan pendidikan, pengawasan dan perhatian terhadap anak-anak mereka. Alasan para informan menggunakan pola asuh tersebut dikarenakan kesulitan yang dijalaninya sebagai orang tua tunggal (single parent) yang harus menyandang peran ganda yaitu sebagai sosok ayah dan juga ibu bagi anakanaknya hingga menyebabkan ibu isngle parent kurang memiliki banyak waktu luang untuk dapat mengasuh serta mengawasi kegiatan anaknya sehari-hari. Namun pengasuhan terbaik tetap ibu single parent usahakan supaya anaknya memiliki perilaku yang baik. Anak mereka tumbuh menjadi anak yang manja, pemarah jika keinginannya tidak dipenuhi, kurang percaya diri dan kurang bisa juga mengendalikan perilakunya.

\section{Saran} saran yaitu :

Berdasarkan hasil penelitian dan kesimpulan yang peneliti lakukan, maka peneliti dapat memberikan

Peneliti berharap untuk setiap keluarga terutama orang tua dan khususnya single parent agar tetap memberikan pola pengasuhan yang baik untuk anaknya walaupun banyak keterbatasan waktu dalam menjalani peran ganda dalam keluarga. Sebab pola asuh yang baik akan mengarahkan dan menghasilkan perilaku baik kepada anak. Pola asuh permissive bisa saja dilakukan oleh setiap single parent namun juga tidak hanya permissive yang diterapkan melainkan juga pola asuh authoritative dikarenakan anak juga akan menjadi investasi terbesar orang tuanya ketika orang tuanya sudah tidak ada lagi didunia ini. Maka dari itu menjadi single parent bukanlah masa kesulitan saja namun masa dimana perjuangan yang sangat berat untuk bisa memperoleh posisinya untuk tetap menjadi orang tua terbaik kepada anaknya.

\section{Daftar Pustaka}

C.Drew, E. (2006). Ketika Anak Sulit Diatur:Panduan Bagi Orang Tua Untuk Mengubah Masalah Perilaku Anak. Bandung: Kaifa.

Depertemen Agama RI. (2014). Al-Qur'an Dan Terjemahnya. CV J-ART.

Hadi, M. F. Z., Yusuf, A. M., \& Syahniar, S. (2013). Pemahaman Konselor Sekolah tentang Tugas Perkembangan Siswa dan Layanan yang Diberikan. Konselor, 2(1).

Hadi, M. F. Z., \& Zubaidah, Z. (2015). Pemanfaatan Konseling Neuro Linguistic Programming dalam Mengatasi Kesulitan Belajar Siswa Sekolah Dasar. Jurnal Dakwah Risalah, 26(4), 174-182.

Husain, T. H. K. (1991). Konsep Ibu Teladan. Surabaya: Risalah Gusti.

L.N, H. S. Y. (n.d.). Psikologi Perkembangan Anak dan Remaja. Bandung: PT Remaja Rosdakarya.

Mutiah, D. (2012). Psikologi Bermain Anak Usia Dini. Jakarta: Kencana.

Nurhayati, T. (2017). Wonderful Parenting. Yogyakarta: Psikologi Corner.

Prawira, P. A. (2014). Psikologi Kepribadian Dengan Perspektif Baru. Jogjakarta: Ar-Ruz Media.

Ruslan, R. (2008). Metode Penelitian Public Relation dan Komunikasi. Jakarta: PT Grafindo Persada. 